Boletín de la Sociedad Geológica Mexicana

VOLUMEN 64, NÚM. 2, 2012, P. 207-213

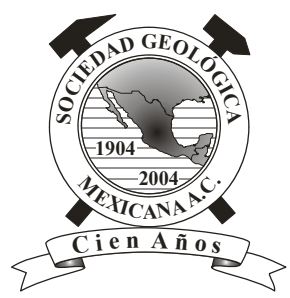

\title{
Objects made of copal resin: a radiological analysis
}

\author{
Naoli Victoria Lona ${ }^{1, *}$ \\ ${ }^{1}$ Posgrado en Antropología, Facultad de Filosofía y Letras/Instituto de Investigaciones Antropológicas, Universidad Nacional \\ Autónoma de México, Circuito Exterior - Mario de la Cueva s/n, Ciudad Universitaria, Coyoacán, México, Distrito Federal, C.P. \\ 04510, México. \\ *naoliv@hotmail.com
}

\begin{abstract}
Since pre-Hispanic times, copal (Bursera bipinnata resin) has been used for different purposes, from medical to ritual or religious, which promoted its transportation from what is now the state of Guerrero to Morelos, Puebla, and Mexico City, as has been verified by ethnographic studies.

During the Late Post-classic period, the resin was transported to Tenochtitlan where it was transformed into different objects such as bars, spheres, conglomerates, bases of sacrificial knives, anthropomorphic figurines and diverse amorphous fragments. The macroscopic and microscopic study of more than 300 copal objects from the offerings of the Great Temple archaeological zone (Templo Mayor) permitted the establishment of a methodology in the manufacturing processes of several formal groups, which were then corroborated by Computerized Axial Tomography, more commonly known by its abbreviated names, CT scan or CAT scan. This radiological technique, created for the study of living human organisms, is very effective in archaeological applications, since it is not invasive but still allows observation of the surface of an object as well as its interior by means of virtual slices. Additionally, it allows the detection of different densities of the components of the object, making it possible to know the composition of different materials.
\end{abstract}

Keywords: Resin, copal, archaeological objects, mexica, Great Temple of Tenochtitlan, Late Post-classical period, computerized axial tomography (CAT).

\section{Resumen}

Desde la época prehispánica el copal (resina de Bursera bipinnata) ha sido utilizado para diferentes fines y contextos, desde uno medicinal hasta uno ritual o religioso, lo que ha promovido su transportación desde el actual estado de Guerrero hacia Morelos, Puebla y la misma ciudad de México, tal como ha sido verificado por los estudios etnográficos realizados en estos lugares.

Así, para el Posclásico tardio, como ha sido comprobado etnográficamente, la resina era llevada a Tenochtitlan donde la transformaban en diferentes objetos como barras, esferas, conglomerados, bases de cuchillos de sacrificio, figurillas antropomorfas y fragmentos diversos amorfos. Gracias al estudio macroscópico y microscópico de más de 300 objetos de copal provenientes de las ofrendas de la zona arqueológica del Templo Mayor, se pudo establecer una constante en los procesos de manufactura de cada grupo formal, siendo sometida dicha observación a una corroboración mediante análisis tales como la Tomografía Axial Computarizada (TAC). Esta es una técnica de principio radiológico creada para el estudio del organismo humano vivo, más se ha descubierto que este tipo de estudio es muy efectivo en la aplicación arqueológica, ya que es una técnica no invasiva que permite observar no sólo la superficie del objeto, sino su interior mediante cortes virtuales, además de detectar las densidades de los elementos inmersos del mismo, es decir, establecer diferentes materiales que le componen.

Palabras clave: Resina, copal, objetos arqueológicos, mexica, Templo Mayor de Tenochtitlan, Posclásico tardío, tomografía axial computarizada (TAC). 


\section{Introduction}

Copal is an immature recent resin, unlike the fossilized, hardened resin that is known as amber (Anderson and Crelling, 1995). It is a name that refers to tree resin used as an aromatic resin by the pre-Columbian Mesoamerican cultures as incense that is burned ceremonially and used for other purposes (Stross, 1997; Ryan et al., 2003). Copal (in Nahuatl: copalli) is obtained from the Bursera tree. In pre-Hispanic times it was known as copalcuáhuitl, or copal tree, and its resin was called "copalli" (incense) (Hernández, 1959; Cruz, 1964; Martínez-Cortés, 1974; Díaz del Castillo, 2000; Sahagún, 2000; Montemayor, 2007).

Copal is one of the vegetal resins that has been used most frequently in ceremonial contexts in Mesoamerica since pre-Hispanic times. Apart from that, it was also used for its medicinal properties (Hernández, 1959; Strucker, 1963; Coggins and Ladd, 1992; Bork et al., 1996; Flores and Ricalde, 1996; Sahagún, 2000). Characteristic of the copal is its peculiar odor and its white smoke while burning, which is believed to facilitate the communication between humans and the deities that govern the earthly order (Berdan and Rieff, 1992, 1997; Sahagún, 2000).

The present analysis is part of an interdisciplinary investigation (Victoria-Lona, 2004) that was one of the first to propose the systematization of the archaeological research of copal. It is based on copal that was found in different mexica contexts of the Templo Mayor archaeological zone, where the Great Temple of Tenochtitlan (Late Post-classical period: 1325 - 1521 AD) is located (Matos-Moctezuma, 1981; López-Luján, 1993; López-Austin and López-Luján, 2002). In order to understand the ancient role of the copal, it was also important to consider its modern production by interlocking archaeological, historical, botanical and ethnographic aspects, including physical, chemical and radiological analyses, such as Computerized Axial Tomography. This analytical technique is more commonly known by its abbreviated names, CT scan or CAT scan (Smith-Bindman et al., 2009).

Two presentations of copal exist from the same tree (Bursera bipinnata) for Mesoamerican area (Rzedowski, 1978; Rzedowski and Guevara-Féfer, 1992; Rzedowski and Calderón de Rzedowski, 1996), the main difference being in the way it is obtained, as well as in its external appearance: gum, stone or wild copal and santa ("saint"), white or penca (leaf of aloe) copal. According to historical sources and ethnographic study, the names date from preHispanic times and are due to its exterior look. The first one exudates naturally on the surface of the trunk in the form of little, mostly grayish drops. A curved knife is used to scratch the surface of the trunk and branches, separating the fragments of fresh copal with a gumlike consistency that look like small stones.

White copal is obtained by making diagonal cuts in the trunk or branches provoking the emanation of the semiliquid milky sap of the tree, which accumulates in agave leaves (Figure 1). As the substance hardens, it takes the form of its container, resulting in bars of white copal. This is the most common form in which this type of resin has been transported since pre-Hispanic times as a tribute from the provinces of Tlachco and Tepecuacuilco, in what is now the State of Guerrero, to Tenochtitlan, now the center of Mexico City. In pre-Hispanic times, every 80 days 8000 packages of wild copal wrapped in maize leaves and 400 baskets of white copal in bars were tribute (Matrícula de Tributos, 1991, fs. 16r-17r; Berdan and Rieff, 1992, fs. 38r-39r); even in some places today, copal is still packed in this way (Figure 2).

\section{Study material and methodology}

\subsection{Formal groups of objects of copal}

The formal classification of the archaeological collection of copal is based on the macroscopic and microscopic analysis of over 300 elements of copal found in 61 offerings. These analyses included the detailed description of each object and its graphic recording (drawing) and photographic recording (Appendix 4 in Victoria-Lona, 2004).

In addition, physical analysis was made, such as: humidity measurement to record how it affects materials, application of hydrochloric acid $(\mathrm{HCl})$ to detect the presence or absence of stucco $\left(\mathrm{CaCO}_{3}\right)$, application of alcohol (copal recovers its properties by rehydrating with a mixture of alcohol - water, 2:1), and exposure to fire to corroborate that it is authentic resin. For this analysis, objects in different stages of conservation were selected from each formal group.

The conservation status refers to the percentage of the preserved object (90\% to $100 \%$ means the object is in good condition, while $20 \%$ represents a poor state of conservation), and the quality of the materials that it contains (stucco compactly adhered to the surface of copal shows a good state of preservation, while stucco that is crumbly or has broken off from the copal represents poor conservation).

Thus, the copal collection has been classified into

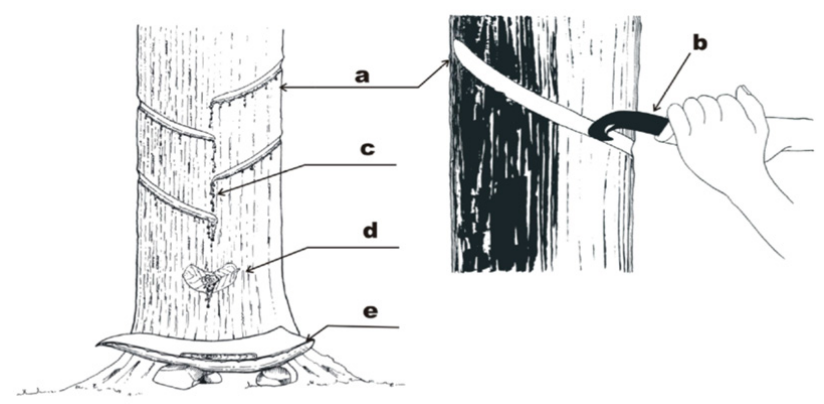

Figure 1. Obtaining copal resin. Extraction of white copal: an incision (a) is made with a curved knife (b); the tree exudes resin (c), which is directed by an oak leaf (d), and is deposited in a larger aloe leaf (e). As soon as the resin hardens, the bar of copal is extracted and is transported to be sold. 

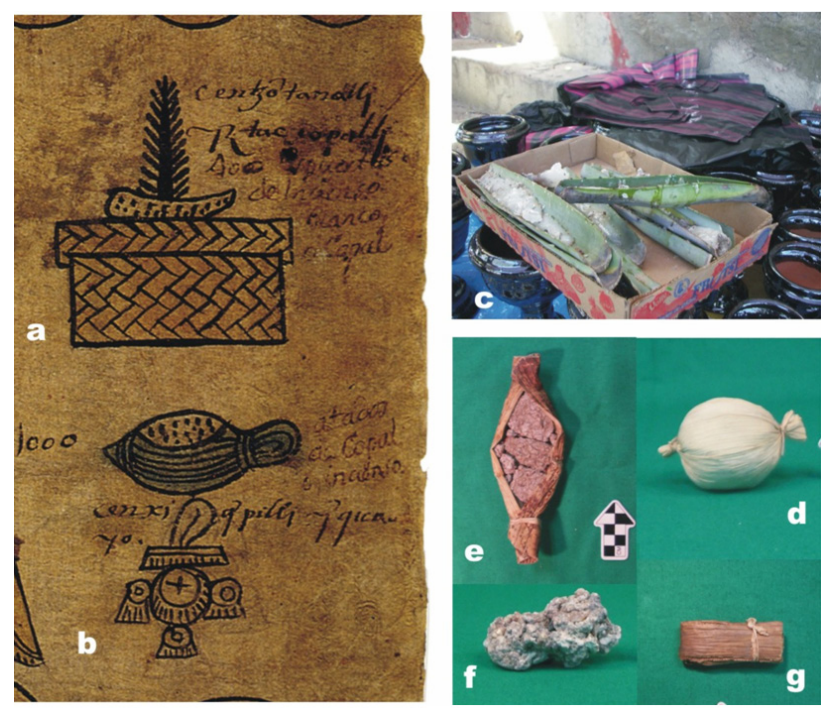

Figure 2. Transportation of the copal, yesterday and today. Representation of white copal kept in a basket on which a bar is observed (a), and wild or gum copal wrapped in corn leaves (b), according to the Matrícula de Tributos (1991), lám. 16r; present-day white (c) and gum copal (e, d, f, g).

six formal groups: bars, spheres, conglomerates, bases of sacrificial knives, anthropomorphic figurines, and miscellaneous fragments, all recovered from the Great Temple of Tenochtitlan and adjacent buildings.

As part of the macroscopic analysis, the manufacturing process was established based on a detailed description, chemical analysis and analysis of the deterioration process of every object in the archaeological collection under consideration. Study of the material in different stages of deterioration was helpful in reconstruction of the manufacturing process, including surface as well as interior features, in order for the hypothesis to be tested.

Understanding the deterioration process allowed us to establish the different stages of of the manufacturing process. Macroscopic analysis was complemented by analyses of radiological type that corroborated some of the hypotheses developed as a result of the first stage of the study.

Once the macroscopic analysis was completed and the formal groups established, representative pieces from each formal group were chosen to be studied by CAT to corroborate the hypotheses related to the prime material by comparing densities, as well as the different stages of the manufacturing process (Table 1).

\subsection{Physical principle of Computerized Axial Tomography (CAT)}

Computerized Axial Tomography is a method of sectional imaging that shows the structures in axial or transverse plane, without overlapping, taking into account the density of the materials in a system of units called Hounsfield units (Figure 3). The analysis of the density of
Table 1. Densities of ancient and modern materials analyzed by Computerized Axial Tomography (CAT), using human studies for calcium, air, water, and corporal fat as a reference. Densities of modern, as well as pre-Hispanic copal were measured in order to compare and determine whether the material is the same, or not.

\begin{tabular}{|cc}
\hline $\begin{array}{c}\text { Hounsfield } \\
\text { units }\end{array}$ & Item \\
\hline 400 & calcium / bone / stucco \\
& \\
60 & diverse elements mixed \\
50 & in with modern and \\
& ancient copal (small \\
& stones, straws, dust) \\
30 & \\
& water \\
0 & synthetic incense \\
-10 & fat \\
-30 & copal \\
-50 & \\
-80 & copal \\
-1000 & air \\
\hline &
\end{tabular}

\section{Scanning principle Image reconstruction}
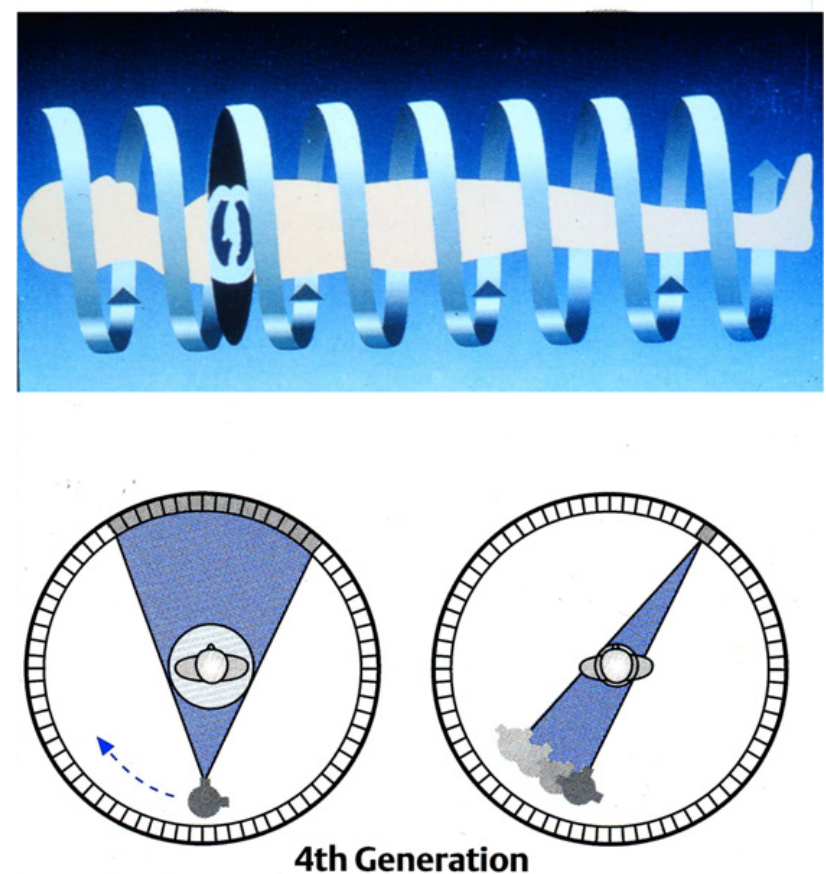

Figure 3. CAT operation. CAT works with sectional imaging that shows the structures in axial or transverse plane, without overlapping, considering the density of the materials. 
human organs generates basic information with values that identify water, muscles and organs, calcium and bone, fat, and air (Harwood-Nash, 1979; Lee et al., 1983).

Eight pre-Hispanic copal objects were chosen as representatives of each formal group: two of 40 spheres, one of seven conglomerates, and five of 80 anthropomorphic figurines. Bars were not taken into account because the ethnographic work shows its origin, nor were the bases of sacrificial knives because the material and manufacturing process were clearly demonstrated with the macroscopic analysis thanks to the different states of preservation; the material classified as miscellaneous was also left out (Table 2).

Some density data was taken from human studies, such as air and calcium, which have a base composition similar to the stucco (calcium carbonate $\left(\mathrm{CaCO}_{3}\right)$ present in the copal anthropomorphic figurines. To establish a reliable comparison, it was necessary to record the density of modern copal, so it could be contrasted with the value of pre-Hispanic material. The density of known incense was included. This incense is burned for its aromatic effect and has a synthetic origin, unlike the copal that is a vegetal resin (Figure 4).

Some materials were identified in the interior of the pieces of copal. The same procedure used for humans was applied to the archaeological material. The piece was placed on the table that slides towards the gantry in order to take the images, to measure densities, and to generate threedimensional images.

To be able to work the resin in all its presentations, heat is necessary to smooth and shape it like clay. Different evidence indicates the application of direct and indirect heat on the vegetal material, such as crystallized areas and stains on one hand, and fingerprints from shaping the resin or warming the resin in pots on the other.

This latter procedure is suggested by Fray Bernardino de Sahagún (2000), who described how copal and other substances like the chapopotli (tar) and the ulli (rubber),

Table 2. Archaeological collection under CAT. Representative samples of copal from the collection of the Templo Mayor Museum, up to 2004, to which CAT was applied in order to corroborate the manufacturing process (materials and methodological steps) observed with the macroscopical analysis

\begin{tabular}{|c|c|c|}
\hline Item & $\begin{array}{c}\text { Total ancient } \\
\text { collection } \\
\text { (up to 2004) }\end{array}$ & $\begin{array}{c}\text { CAT } \\
\text { Samples }\end{array}$ \\
\hline bars & 6 & none \\
\hline spheres & 40 & 2 \\
\hline conglomerates & 7 & 1 \\
\hline base of sacrifical knives & 42 & none \\
\hline male anthropomorphic figurines & 53 & 3 \\
\hline female anthropomorphic figurines & 19 & 2 \\
\hline indeterminate anthropomorphic figurines & 8 & none \\
\hline miscellaneous & 138 & none \\
\hline Item total & 313 & 8 \\
\hline
\end{tabular}

were crumbled to melt them in pots that were placed on embers in order to make medicinal ointments or a kind of cream. It is probable that the copal resin was warmed in the same way to manufacture objects.

\section{Results}

\subsection{Bars of white copal}

The ethnographic study of copal helped significantly to understand the manufacture of the bars and "tears" because, as previously mentioned, the fresh resin takes the shape of the agave leaf which is used like a mold and the consequent marks are visible on the surface.

\subsection{Spheres and conglomerates of gum and white copal}

These objects are asymmetric but with a clear general shape, showing small visible depressions possibly caused by finger pressure, and in other cases resulting from smoothing or polishing.

The process of manufacture starts by joining fragments of the resin in order to make a spherical nucleus. Concentric layers are added until the desired form and size is obtained, leaving spaces between every layer and the fragments of copal adhered, as seen in the radiological analysis (Figure 5).

The external layer of the object was smoothed or polished, and subjected to heat in order to enhance the adhesive properties of the resin and to assure the consolidation of the piece.

\subsection{Bases of sacrificial knives of gum and white copal}

The principle is similar to that of the spheres and conglomerates, the difference being that the fragments of copal do not stick to a nucleus of resin, but to the proximal section of the knife starting with the flat faces, and later, the

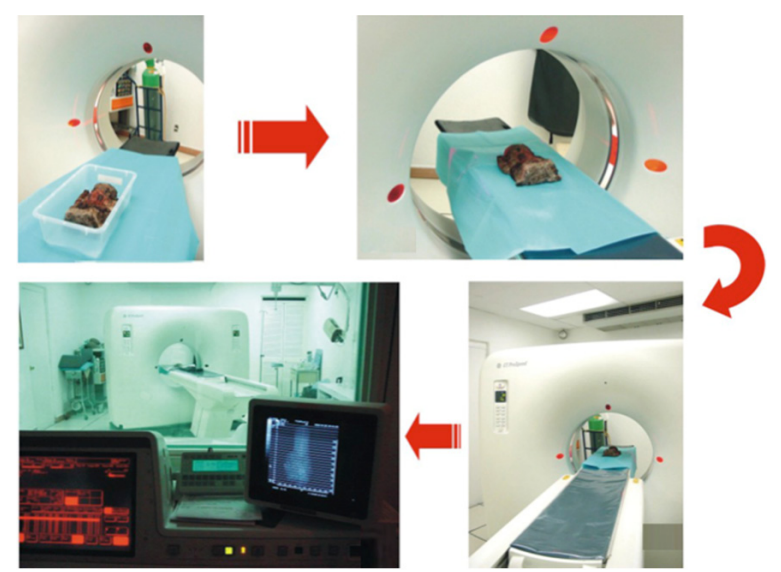

Figure 4. CAT applied to archaeological copal. Analysis of the archaeological pieces with $\mathrm{CT}$. 
lateral ones. The object is then smoothed or polished. Fire or heat is applied in order to consolidate the components.

\subsection{Anthropomorphic figurines of white copal}

The process of manufacture of anthropomorphic figurines was established on the basis of the analysis of 80 pieces from this group, composed of 19 female figurines, 53 male figurines and eight of indeterminate genre as a result of poor conservation.

A nucleus of copal is evident, with specific facial and corporal characteristics, made by joining fragments of resin in a mold until it is filled. The nucleus is then covered with a layer of stucco, using a double mold where the representation of facial and corporal features is evident, such as apparel.
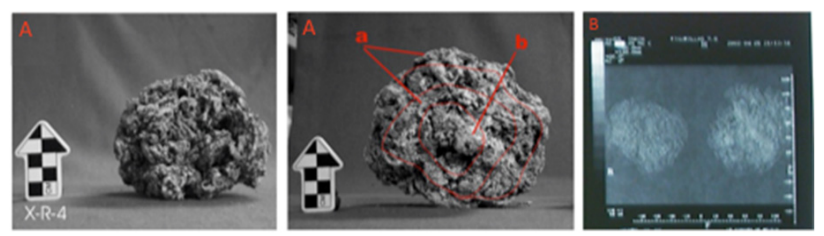

Figure 5. Macroscopic and radiological analysis. (A) The archaeological objects and (B) the tomographic view show that they were shaped in concentric layers (a) around a central nucleus (b).
Finally the figurines are decorated by pigments and garments made of paper, and occasionally complementary elements such as flags (Figure 6).

\section{Discussion}

Copal is a resin that has been used since pre-Hispanic times, with both curative and religious uses, which was burned and buried in diverse forms. There are two types of copal produced by the same tree: gum, stone or wild copal and the "saint" (santa), white or penca (leaf of agave) copal. These two kinds of archaeological copal were found in the Great Temple (Templo Mayor archaeological zone) and are both observed in massive forms and in small leaves or flakes.

The archaeological collection (of over 300 elements of copal found in 61 offerings) has been classified in six formal groups: bars, spheres, conglomerates, bases of sacrificial knives, anthropomorphic figurines, and miscellaneous fragments.

The manufacturing process was established based on a detailed description of every object. For the successful manufacture of copal objects, it was necessary to soften the resin, thus the application of heat is an essential part of the process.

At the moment when the material is obtained, the fresh
White copal nucleus
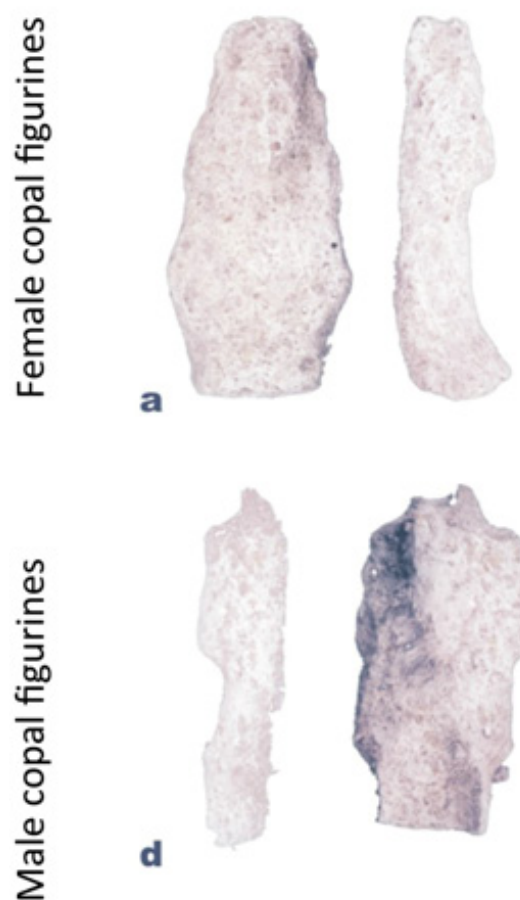

\section{Stucco cover}
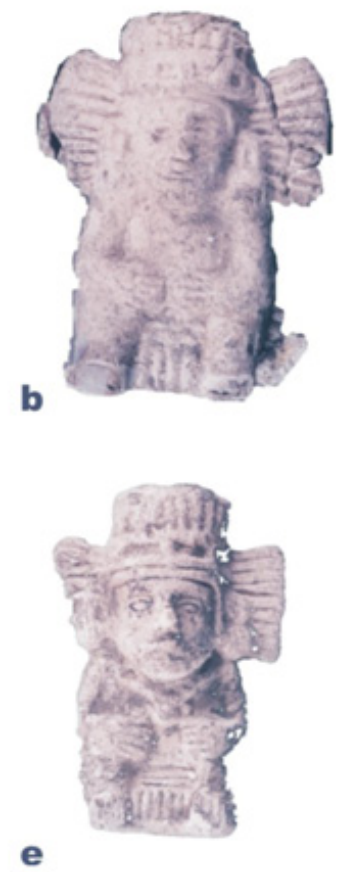

Decoration with pigments and paper dresses
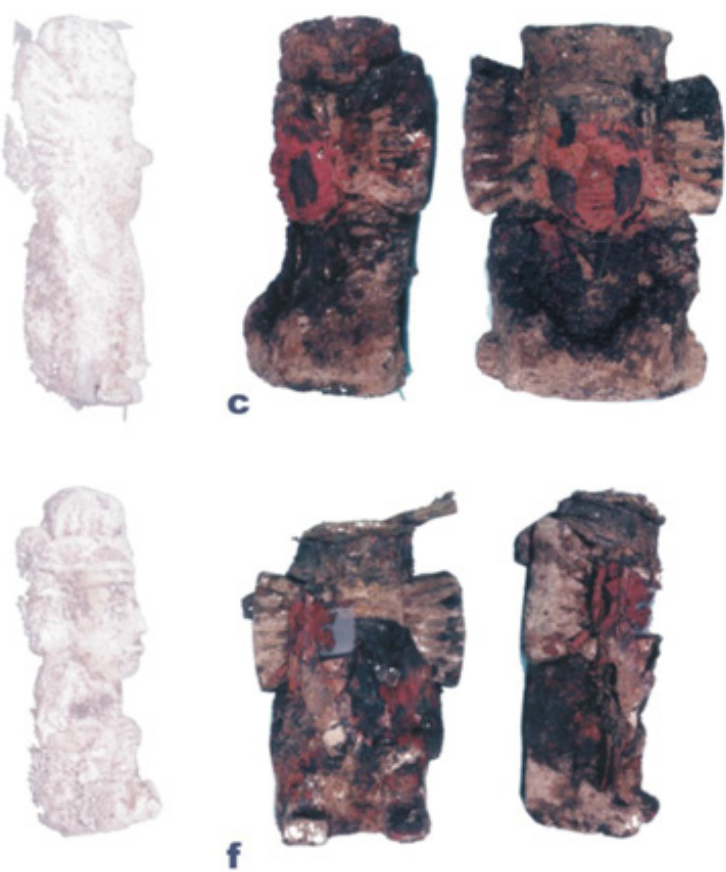

Figure 6. The manufacturing process of resin figurines. The nucleus of copal (a, d) is covered by a stucco layer (b, e) decorated with pigments and paper dresses (c, f). 
resin takes the shape of the agave leaf used like a mold and the consequent marks are visible on the surface creating the bars of copal; but sometimes the resin spills, and the drops are called lágrimas (tears).

Resin fragments were commonly adhered together to obtain the desired forms, and surface was smoothed to give the appearance of a single unit, such as for the spheres, conglomerates and bases of sacrificial knives.

The figurines were elaborated by shaping a nucleus of copal with stucco covering, across which the decoration was placed.

The process of deterioration is useful in reconstructing the manufacturing process of the copal objects; the first stage of the study consisted of macroscopical and microscopical observations. These were complemented with CAT, which is a noninvasive technique. It analyzes the objects in different thin layers, identifying their densities. These densities can be classified according to a table of comparison, which was first established from the macroscopical observations and the analysis of physical types, and second, from all the chemical types of the representative samples of the copal study collection.

The complement of both analyses allowed us to establish the manufacturing process and the materials of which the copal objects were made. Although the copal was the predominant material, stucco (ground limestone), small stones, straw, paper, pigments, and other materials, were used as well. The most important contribution is that all this was possible without destroying the archaeological material (Figure 7).

\section{Conclusions}

The macroscopic analysis of more than 300 objects made of copal provides an important base to propose and to corroborate the manufacture hypothesis.
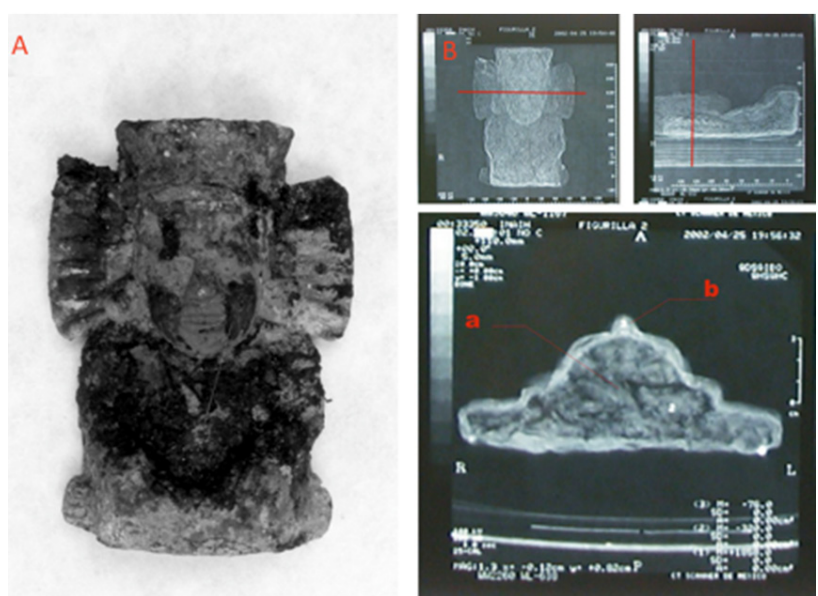

Figure 7. Manufacturing process corroborated with CAT. The tomography (B) of the archaeological copal figurine (A) shows clearly the copal nucleus (a) that is wrapped by the stucco layer (b).
The use of analytic tools of different disciplines, such as the invaluable contribution of Computerized Axial Tomography, allowed us to corroborate the macroscopic observations, thus providing more information about the technical process of manufacture, such as the materials used in the manufacture of the objects without destroying the archaeological pieces, because it is a non-invasive and very exact tool.

\section{Acknowledgments}

We acknowledge the support of José Luis Criales, director of CT Scanner de México, Leonardo López Luján from the Museo del Templo Mayor, Instituto Nacional de Antropología e Historia; Jorge E. Gama, Carolina Jasso, and Leticia Alba from the Instituto de Geología, Universidad Nacional Autónoma de México; Adrián Benítez, Daniela Huber, José Luis Hernández, Julio Emilio Romero, and the people who made the ethnographic work possible, as well as many specialists from different areas who participated in developing this research. We culminated this study thanks to the enthusiasm of all those who supported this research.

\section{References}

Anderson, K.B., Crelling, J.C., 1995, Amber, resinite, and fossil resins: American Chemical Society. Washington, DC: American Chemical Society. ACS Symposium Series No. 617. 297p.

Berdan, F.F., Rieff, P.A., 1992, The Codex Mendoza: Berkeley, University of California Press, 1997 xii, 436 p.

Berdan, F.F., Rieff P.A., 1997, The Essential Codex Mendoza: Berkeley, University of California Press, $436 \mathrm{p}$.

Bork, P.M., Schmitz, M.L. Weimann, C., Kist, M., Heinrich, M., 1996, Nahua Indian medicinal plants (Mexico): inhibitory activity on NF-kB as an anti-inflammatory model and antibacterial effects: Phytomedicine, 3, 263-269.

Coggins, C.C., Ladd, J.M., 1992, Copal and rubber offerings: Memoirs of the Peabody Museum of Archaeological \& Ethnology, 10, 345-357.

Cruz, M. de la, 1964, Libellus de Medicinalibus Indorum Herbis (también llamado Códice de la Cruz-Badiano). Manuscrito Azteca de 1552. Según traducción latina de Juan Badiano. Versión española y comentarios por diversos autores: México, Instituto Mexicano del Seguro Social. 349 p.

Díaz del Castillo, B., 2000, Historia verdadera de la conquista de la Nueva España. Antología. Estudio introductorio y selección Miguel LeónPortilla: México, CONACULTA, Cien de México 298p.

Flores, J.S, Ricalde, R.V., 1996, The secretions and exudates of plants used in Mayan traditional medicine: Journal of Herbs, Spices \& Medicinal Plants, 4, 153-159.

Harwood-Nash, D.C., 1979, Computed Tomography of Ancient Egyptian Mummies: Journal of Computer Assisted Tomography, 3(6), 768773.

Hernández, F., 1959, Historia natural de Nueva España: México, Universidad Nacional Autónoma de México, II, libro 4, 666p.

Lee, J.K.T., Sagel, S.S., Stanley, R.J., 1983, Computed Body Tomography: New York, Raven Press, 1-5.

López-Austin, A., López Luján, L., 2002, La periodización de la historia mesoamericana: Arqueología Mexicana, 11, 6-15.

López-Luján, L., 1993, Las ofrendas del Templo Mayor de Tenochtitlan: México, Instituto Nacional de Antropología e Historia, 438p. 
Martínez-Cortés, F., 1974, Pegamentos, gomas y resinas en el México prehispánico: México, SEP Setentas, 158p.

Matos-Moctezuma, E., 1981, Una visita al Templo Mayor de Tenochtitlan: México, Secretaría de Educación Pública/Instituto Nacional de Antropología e Historia, 77p.

Matrícula de Tributos, Nuevos Estudios, 1991, Interpretación de Víctor M. Castillo y Ma. Teresa Sepúlveda: México, Edición facsimilar de la Secretaría de Hacienda y Crédito Público, 154 p.

Montemayor, C., 2007, Diccionario del náhuatl en el español de México: México, Universidad Nacional Autónoma de México-Gobierno del Distrito Federal, $57 \mathrm{p}$.

Ryan, J., Tucker, A.O., Maciarello, M.J., Wheeler, K.A., 2003, Chemistry and Ethnobotany of Commercial Incense Copals, Copal Blanco, Copal Oro, and Copal Negro of North America: Economic Botany, 57(2), 89-202.

Rzedowski, J., 1978, Vegetación de México: México, Limusa, 504p.

Rzedowski, J., Calderón de Rzedowski, G., 1996, Burseraceae, in Flora de Veracruz: Xalapa, Veracruz, Instituto de Ecología, 94, 37 p.

Rzedowski, J., Guevara-Féfer, F., 1992, Familia Burseraceae, in Flora del Bajío y de regiones adyacentes: Centro Regional del Bajío, Pátzcuaro, Michoacán, CONACYT / SEP, Instituto de Ecología, Xalapa, Veracruz, 3, $46 \mathrm{p}$.

Sahagún, B. de, 2000, Historia General de las cosas de Nueva España, 3 vols. Estudio introductorio, paleografía, glosario y notas Alfredo López Austin y Josefina García Quintana: México, Cien de México / CONACULTA, 1450p.
Smith-Bindman, R., Lipson, J., Marcus, R., 2009, Radiation dose associated with common computed tomography examinations and the associated lifetime attributable risk of cancer: Archives of Internal Medicine, 169(22), 2078-86.

Stross, B., 1997, Mesoamerican copal resins: Austin, University of Texas at Austin, U Mut Maya, VI, 177-186.

Strucker, J. D., 1963, Some ritual aspects of the use of copal among ancient and present-day Maya speakers: Harvard University Freshman Seminar Program 1, 1-16.

Victoria-Lona, N., 2004, El copal en las ofrendas del Templo Mayor de Tenochtitlan: México, D. F., Escuela Nacional de Antropología e Historia, tesis de licenciatura, 295p.

Manuscript received: December 22, 2010.

Corrected manuscript received: June 14, 2011.

Manuscript accepted: April 10, 2012. 